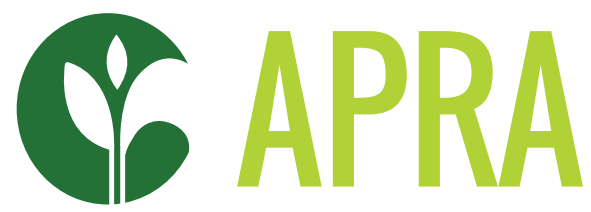

Agricultural Policy Research in Africa

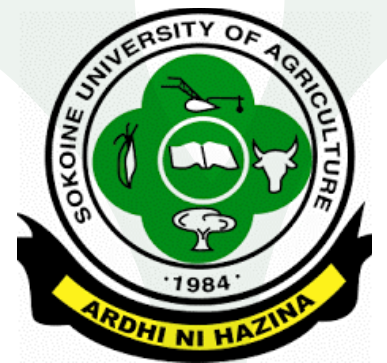

\title{
THE POLITICAL ECONOMY OF SUNFLOWER IN TANZANIA: A CASE OF SINGIDA REGION
}

\author{
Aida C. Isinika and John Jeckoniah
}




\section{CONTENTS}

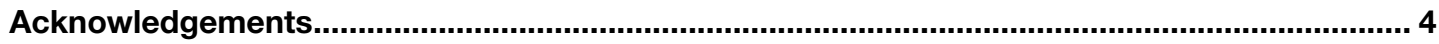

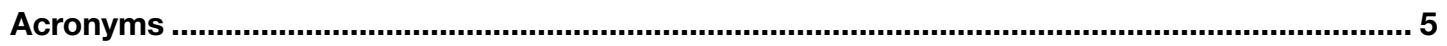

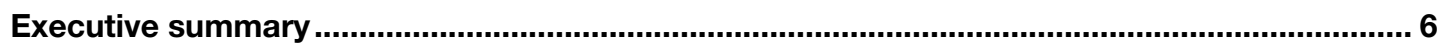

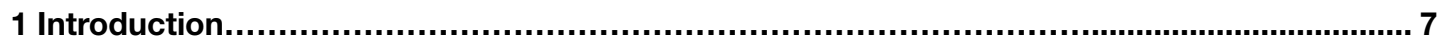

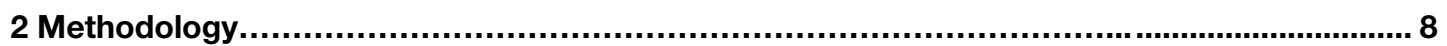

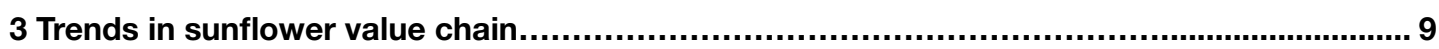

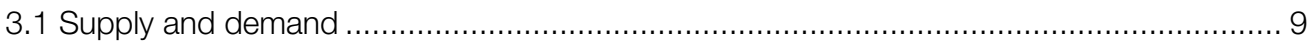

3.2 Trend of sunflower production and processing .......................................................... 9

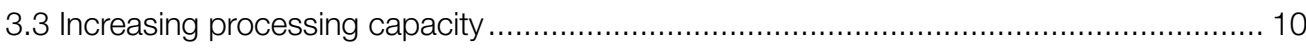

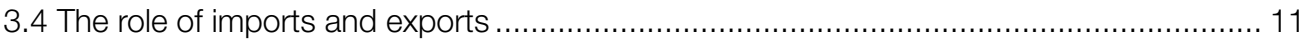

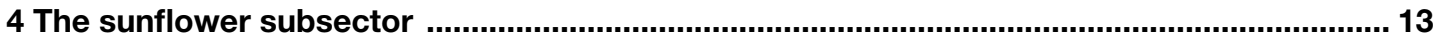

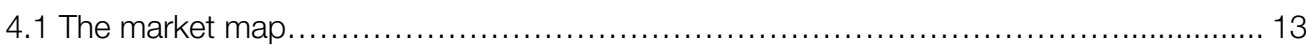

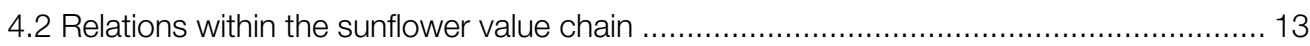

5 Policies and strategies for growth of the sunflower subsector.............................................. 20

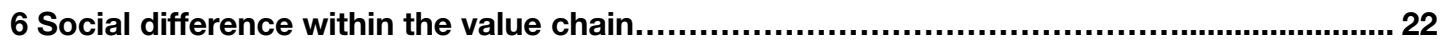

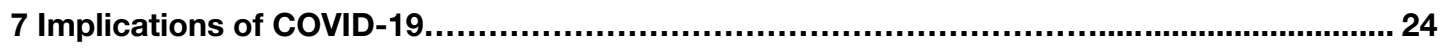

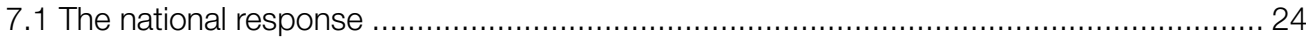

7.2 Pandemic effects on sunflower production and marketing ........................................ 24

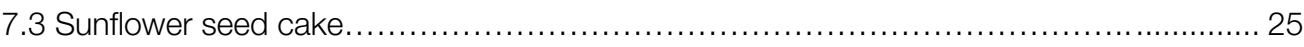

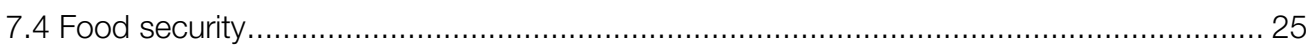

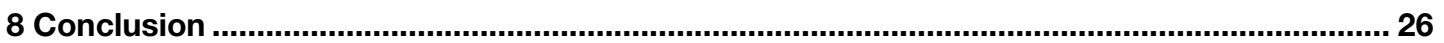

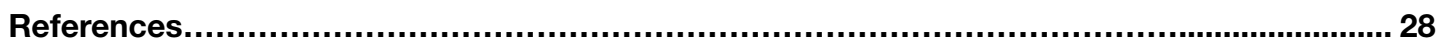

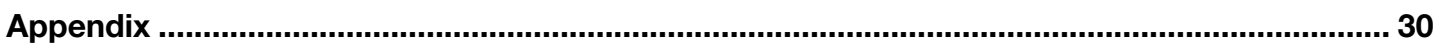

Appendix 1 Selected medium- and large-scale old and new edible oil processors

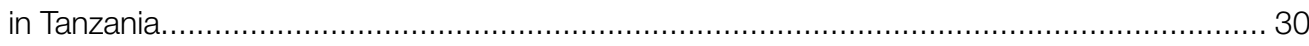

Appendix 2 Wealth ranking criteria for qualitative study in Iramba and Mkalama

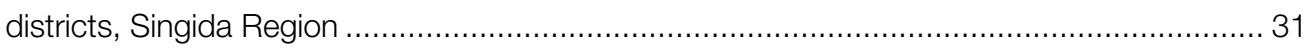

Tables

Table 3.1 Sunflower seed, oil and cake exports (,000 US\$): 2005-2016 ........................... 12

Table 4.1 Tanzania export of sunflower products (US\$ millions) …….................................. 19

Figures

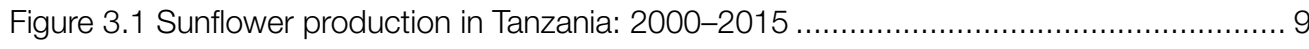

Figure 3.2 New oil mills installed in selected villages of Iramba and Mkalama districts .......... 10

Figure 3.3 Total imports of crude oil to Tanzania: 2012-2014 ......................................... 12 
Figure 4.1 General sunflower subsector value chain in Tanzania................................... 13

Figure 4.2 Detailed sunflower sector market map (actors and service providers) .................. 14

Figure 4.3 Enabling environment and service providers.......................................... 15

Figure 4.4 Total land owned by different categories of farmers................................... 15 


\section{ACKNOWLEDGEMENTS}

Funding for this research is provided by Agricultural Policy Research in Africa (APRA); a five-year research programme consortium funded by the Foreign, Commonwealth \& Development Office (FCDO). The programme, which is based at the Institute of Development Studies (IDS) (www.ids.ac.uk), builds on more than a decade of research and policy engagement work by the Future Agricultures Consortium (www.future-agricultures.org). We are grateful for all the farmers, traders, processors, government staff and other key informants in the country and in Singida Region in particular who gave their time to share their experiences and stories about the sunflower value chain. The research team also appreciates the feedback given by APRA members, particularly from the internal and external reviewers as well as the coordinating secretariat at IDS.

Aida Isinika is a retired Professor of Agricultural Economics from the Institute of Continuing Education (ICE), Sokoine University of Agriculture in Tanzania (SUA). John Jeckoniah is a professor in the Department of Development Studies (DDS) from Sokoine University of Agriculture.

This working paper is funded with UK aid from the UK government (Foreign, Commonwealth \& Development Office - FCDO, formerly DFID). The opinions are the authors and do not necessarily reflect the views or policies of IDS or the UK government. 


\section{ACRONYMS}

\begin{tabular}{ll} 
ADT & animal drawn technology \\
AMCOS & Agricultural Marketing Cooperative Society \\
APRA & Agricultural Policy Research in Africa \\
CARMATEC & Centre for Rural Mechanisation and Agriculture Technology \\
CPO & crude palm oil \\
FHH & female-headed household \\
IGA & income generating activity \\
LGA & local government authority \\
MHH & male-headed household \\
MITI & Ministry of Trade and Investment \\
NGO & non-governmental organisation \\
NREP & National Rural Electrification Programme \\
RAS & regional administrative secretary \\
RLDC & Rural Livelihoods Development Company \\
REA & Rural Energy Agency \\
SNV & Netherlands Development Organisation \\
TADB & Tanzania Agriculture Development Bank \\
TANESCO & Tanzania National Electric Supply Company Limited \\
TASUPA & Tanzania Sunflower Processors Association \\
TCCIA & Tanzania Chamber of Commerce, Industry and Agriculture \\
VAT & value-added tax \\
\hline MA &
\end{tabular}


Since the early 1990s, sunflower has evolved from an obscure subsistence crop to become an important cash crop, now produced in all regions of Tanzania. Increasing sunflower production has been a response to rising demand for sunflower oil in the local and export market. Tanzania, as the second most important producer of sunflower in Africa and the $10^{\text {th }}$ in the world, is poised to become an important supplier of sunflower seed and sunflower products (oil and seed cake) in the regional and global markets, while also meeting local demand.

This paper presents the political economy of sunflower in Tanzania based on analyses of the sector performance over a 30-year period since the early 1990s. We examine relations among two core sunflower stakeholders. First, the importers of edible oil are dominated by crude palm oil and are keen to protect their market share and influence, since they supply more than 50 per cent of local demand. Second, the aims of local actors of the sunflower value chain (farmers and processors) to increase their market share in the domestic and export market are the opposite of the importers. The importers, and the farmer and processors, both try to influence national policies and strategies in their favour.

We find that both sunflower production and processing capacity have trended up since the year 2000. Sunflower production has mostly benefited from area expansion as mostly smallholder farmers, of 2 ha or less, have engaged in the value chain. Higher yielding varieties have also improved productivity, especially since 2010 as farmers adopted imported hybrid seed and improved agronomic practices.

Sunflower commercialisation has also changed the institutional framework for managing livestock, forcing large owners to redistribute their herds to poorer neighbours as caretakers. These neighbours have benefited from milk and cultivation services, thereby reducing inequality in access to livestock as assets but also to related goods and services. The improvement in processing technology has resulted in more male dominance, especially in post-harvest processes (marketing and processing).

We also discuss in this paper how disparities in accessing resources for production were established across gender, age, wealth status which led to social differentiation. Consequently, poorer households and women, especially female-headed households (FHHs), benefit less from sunflower commercialisation. Likewise, actors at marketing and processing nodes are predominantly male, but both men and women benefit from existing services.

We also address how the COVID-19 pandemic has affected activities and relations along the sunflower value chain. Tighter restrictions introduced by the government affected the marketing and processing of sunflower seed. Prices declined, as did the sales of products such as seed cake, as transport to neighbouring countries and export routes slowed down.

As the findings above indicate, our study examines the challenges and shortcomings facing the sunflower sub-sector. However, an honest appraisal of the current sunflower strategy operating since 2016, and opportunities on how to improve it, is needed to prepare the sector for the next ten years and beyond. 
In Tanzania, the importance of sunflower as a source of cash income has significantly increased during the last 20 years. This paper sets out to understand the basic underlying political economy dynamics of sunflower production, processing and marketing in Tanzania, with a particular focus on the drivers and constraints of agricultural commercialisation. In addition, social difference and women's empowerment in the context of agricultural commercialisation is assessed and discussed. The discussion is guided by the Agricultural Policy Research in Africa (APRA) programme's political economy studies, which has been interested in addressing questions such as:

- Who wins and who loses from agricultural commercialisation?

- What are the institutional incentives and forms of public support that drive different commercialisation pathways? What were the salient political conditions under which diverse commercialisation initiatives were pursued?

- What assists and what prevents effective 'pro-poor' change? Which political variables, if any, appear to influence the outcomes observed under given commercialisation pathways?

To achieve this we use mixed methods, drawing from the local agrarian conditions and the wider political economy to understand the local processes of production, accumulation and livelihoods using microlevel household survey data (Dancer and Hossain 2018).

In this context, the paper reviews the trend of sunflower production, marketing and processing in Tanzania during the last 20 years to establish the dynamics and outcomes in terms of power relations and influence vis a vis outcome indicator for livelihoods, food security and inclusion. While the study uses national secondary data from various sources, we draw on specific insights from Singida Region, one of the leading sunflower producing regions in the country, where APRA has been conducting a study on sunflower commercialisation since 2017.
In the second chapter, we present the methodology, followed by background information in Chapter Three that presents important factors about the sunflower value chain in Tanzania. These include trends of supply and demand of sunflower oil, sunflower seed production and processing, the effects of edible oil imports on the supply response of sunflower seed and sunflower products from farmers and processors. In Chapter Four, we describe a market map of the sunflower sub-sector, followed by discussion about relations between actors and service providers. These include enabling institutions along the sunflower value chain, including production, marketing, processing, and markets for sunflower products. In Chapter Five, we present future strategies for growth of the sunflower sub-sector up to the year 2030 as outlined by the government. This is followed by discussion about social differentiation of actors within the value chain and their implications in terms of power relations, economic and social inclusion. Chapter Seven covers the effects of the COVID-19 pandemic, which hit the world in 2020. Although the severity of the pandemic was milder in Tanzania compared to other parts of the world, the pandemic nonetheless affected the marketing of sunflower seed and products, especially sunflower oil and seed cake due to disrupted travel arrangement and reduced demand from consumers due to restricted movement between March and June 2020 and more cautious demand due to reduced income. Conclusions are presented in the final chapter. 


\section{METHODOLOGY}

In this study we undertook a comprehensive literature review and a systematic analysis of existing studies on the sunflower value chain. The review was guided by the APRA objectives on political economy of sunflower in Tanzania, as well as the study area in the Singida region. A descriptive analysis of the results from different studies was conducted to explore existing evidence on the power relation of actors in terms of interests, power and influence on policymaking among actors involved in the sunflower value chain. Eleven studies were collected from different authors and publications. Information from the literature review were verified and complimented through stakeholder's interviews in order to ascertain and overcome selection biases or errors and to have more location-specific evidence and practices in the sunflower value chain within the Tanzanian context. More than 30 stakeholders were interviewed to gain a better understanding of the policymaking processes, implementation and the impact of the policy issues in the sunflower value chain for different actors. Consultations with key informants were guided by a standard check list developed for data collection. Consultations were conducted with key government ministries, regional/ local government, large-scale processors, industry associations and private sector support. The consulted organisations included: Sunflower Farmers Association (SUFA), the Tanzania Sunflower Processors Association (TASUPA), Singida Sunflower Processors Association and Singida Sunflower Farmers Association. In addition, a selection of private sector support organisations, including the Tanzania Chamber of Commerce, Industry and Agriculture (TCCIA) and the Tanzania Private Sector Foundation were interviewed. The Regional Administrative Secretary Office and District Executive Directors were also consulted. In addition, farmers, traders, processors, input suppliers were also consulted in relation to production, processing, and marketing, as well as on the impact of COVID-19 on their sunflowerrelated and other economic activities. 


\section{TRENDS IN THE SUNFLOWER VALUE CHAIN: AN OVERVIEW}

\subsection{Supply and demand}

The global and regional trend of demand for edible oil is ever increasing, which has attracted many countries to join the subsector, supporting primary producers, processors and other actors along the value chain. This trend is mirrored in Tanzania, where sunflower has evolved from an obscure subsistence crop that was produced in only a handful of regions in 1990 to its current state, replacing groundnuts to become the leading domestically produced oil crop. Sunflower accounted for nearly 49 per cent of oil seed produced in 2013/14 (BOT 2017). Tanzania ranks tenth among sunflower producers in the world and second in Africa, after South Africa. Within East Africa, Tanzania is the leading producer, having the highest area under production and the highest output of sunflower seed (Dalberg 2019). Estimates show that Africa accounts for 5.5 per cent of the world's production, and Tanzania accounts for 35 per cent of Africa's share (BOT 2017). However, local production of oilseeds in Tanzania only meets about 30-45 per cent of the demand. Hence, Tanzania imports between 55 and 70 per cent of edible oil (Salisali 2017, cited by Balchin et al. 2018).
The demand gap presents an opportunity for both local producers and processors of sunflower seed as well as importers of sunflower oil substitutes. Recent analyses of the sunflower sub-sector show that Tanzania has significant potential to increase its competitiveness (BOT 2017; RLDC 2010). Since the 1990s, the government has made various efforts to increase local production and processing capacity to meet rising local demand. As local production and processing capacity increased, local sunflower processors, in particular, have lobbied for protection against cheaper imports. At the same time, edible oil importers constitute a strong lobby group whose interest has been to advocate for reduced import taxes. These lobby groups characterise the political economy of sunflower production, marketing and processing in Tanzania.

\subsection{Trend of sunflower production and processing}

Sunflower was introduced in Tanzania during the colonial times. Until the 1970s, it remained a minor crop, mostly produced in the central zone led by Singida and Dodoma regions. Processing was mostly done at home by women using a mortar and pestle followed

Figure 3.1: Sunflower production in Tanzania: 2000-2015 (FAOSTAT)

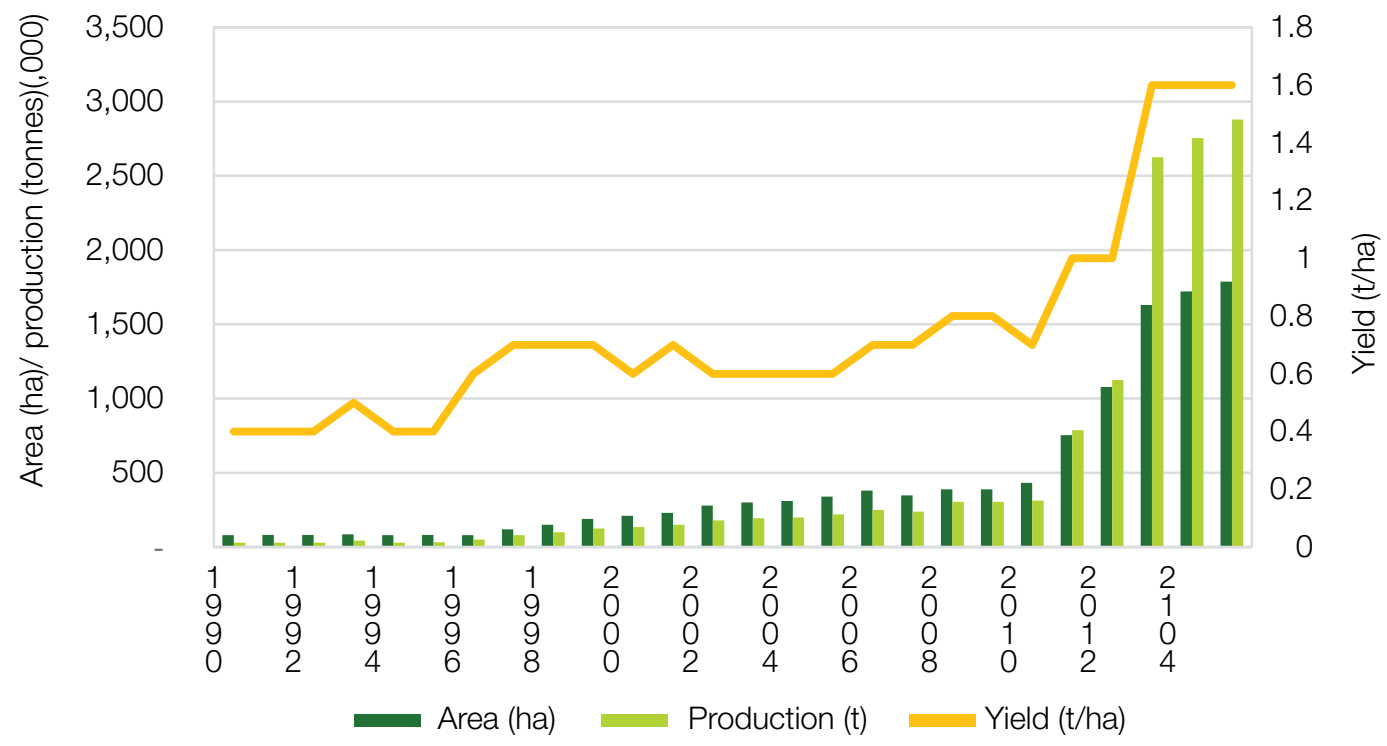

Adapted from: FAOSTAT 
by boiling the powder to extract oil for domestic consumption or for sale in local markets. During the 1990s government extension services working with various non-governmental organisations (NGOs) and development agencies promoted sunflower for poverty reduction in the central zone of Tanzania, facilitating improvement of agronomic practices and introducing simple processors (Isinika and Mwajombe 2019). At the same time, research stations under the Ministry of Agriculture released several higher yielding sunflower seed varieties. Hence, since the year 2000, sunflower production exhibited a gradual upward trend until 2010 and an accelerated trend thereafter (Figure 3.1). Currently, sunflower is produced in almost all regions of mainland Tanzania (Mgeni et al. 2018). However, reduced funding for research led to a decline in the availability of improved seed. This trend, coupled with general low use of fertiliser and organic manure among farmers, triggered a declining trend in yields, reducing farmers' returns from sunflower production, which also slowed the rate of area and production increase from around 2008 (Figure 3.1).

Rising production attracted increasing processing capacity, and diesel-powered processing facilities were introduced through NGOs and the private sector. Improved processing in turn enticed farmers to increase production, mostly through area expansion, but also using improved seed and better agronomic practices to attain higher productivity. As commercial production increased from 1990 onwards, postharvest handling of sunflower seed gradually shifted from women to men who increasingly managed post-harvest handling, especially selling. Men took over control of the sunflower value chain when processing changed from a pounding and boiling activity by women to modernised processing requiring men to ferry bags of sunflower seed on bicycles, motorcycles or trucks to processing facilities, often located outside their respective villages. The male takeover of sunflower post-harvest handling sounded logical at the time as it relieved women from the burden of having to carry the sunflower seed to distant mills. However, this transition was also disempowering as women lost control of cash income from sunflower (Mosha et al. forthcoming; Isinika et al. 2020).

\subsection{Increasing processing capacity}

During the 1980s and 1990s, increasing processing capacity was driven by initiatives to promote appropriate technology through the Small Industries Development Organisation (SIDO) and the Centre for Rural Mechanisation and Agriculture Technology (CARMATEC). Development agencies supported women and farmers' groups to acquire mini-oil presses but most of them were not sustainable due to managerial and technical challenges. Managerial challenges were prevalent due to collective ownership of the mini-oil presses. Group-owned productive assets have had a poor performance record not only in Tanzania, but elsewhere in the world due to poor leadership, embezzlement of funds and poor or irregular maintenance. Such experience cuts across all types of groups (men, women and mixed groups) (Markelova and Mwangi 2010). The managerial challenges bred technical challenges due to irregular and sometimes poor maintenance leading to eventual collapse of the communally-owned processing enterprises. Meanwhile, most of the privately-owned mills sustained until they were replaced by electric mills due to better management (Isinika and Mwajombe 2019).

Increasing production and expanding availability of electricity attracted investors into processing, especially in the central zone (Dodoma and Singida regions). For example, in Iramba and Mkalama districts (Singida Region), the number of new sunflower processors has been increasing slowly at first but trending up between 2012 and 2016 (Figure 3.2), consistent with increasing

Figure 3.2: New sunflower oil mills installed in selected villages: Iramba and Mkalama districts

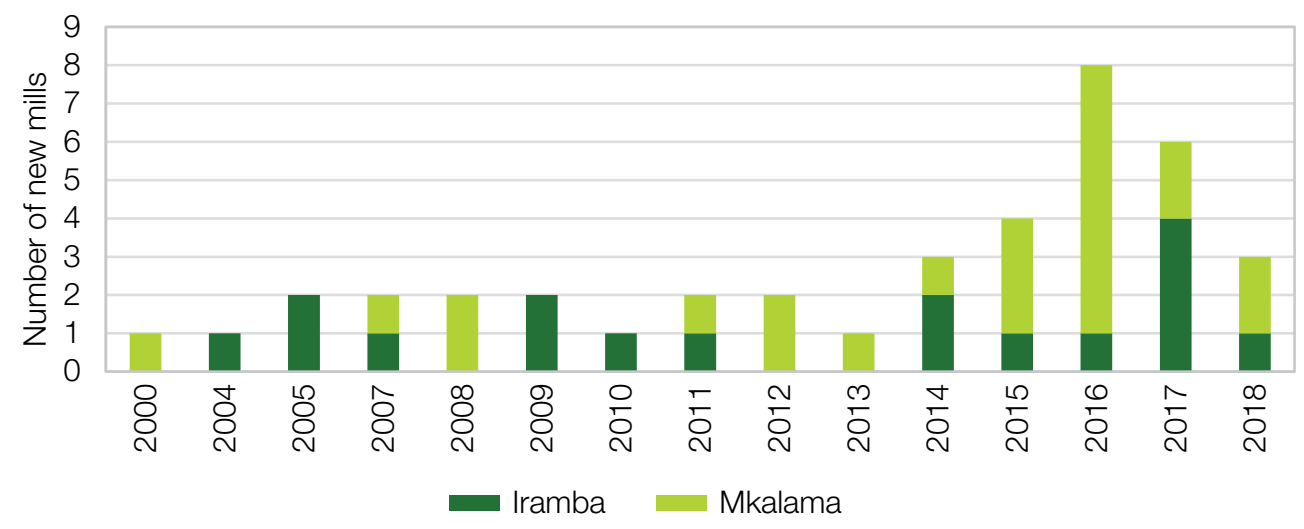

Adapted from: FAOSTAT 
sunflower production levels (Figure 3.1). As the national electricity grid passed through the central regions during the 1970s, on transit to the lake zone, small diesel sunflower processing machines were replaced by larger and more efficient oil mills. Electrification during the 1970s, and trunk road improvement during the 1990s up to the present, have been major drivers of sunflower expansion and commercialisation in Tanzania. These road infrastructure improvements, initially focused in the Central Zone, are now extending countrywide (Magomba and Gideon 2020; Isinika and Mwajombe 2019).

In 2005, the government enacted the Rural Energy Act to facilitate rural electrification. The Rural Energy Agency was subsequently established to coordinate this initiative, extending the national grid to rural areas. The pace of rural electrification is guided by the National Rural Electrification Programme (2013-2022), under which, Tanzania intends to increase the electricity access rate from 24 per cent in 2016 to 35 per cent by 2022 (NBS and OCGS 2013). This electrification programme has been associated with installation of many small and a few large sunflower processing machines in rural villages. As soon as electricity is connected to a village, investors step in to install smallsized processing machines, which are accessible in the local market and affordable by local investors. This second wave of expanded sunflower processing capacity (since 2014) is reflected using data on new oil mill installation from selected villages in Iramba and Mkalama districts (Figure 3.2).

Singida Region which, as alluded to earlier, is one of the leading sunflower producing regions in Tanzania, accounts for over 20 per cent of national sunflower seed production. This region is located in the central zone of Tanzania, along the central railway line to Mwanza and Kigoma. Besides sunflower, Singida is also famous for producing onions and for raising livestock. Being a leading producer of sunflower, the number of oil presses increased from 50 units in 2007 to 90 units in 2011, with Iramba District recording the highest growth (Selemani 2018) and the total number of oil mills installed nationwide is over 1,000 (Dalberg 2019). The increasing trend of sunflower seed production, from 2011 has been driven by several factors, including: area expansion facilitated by animal drawn technology, and higher productivity as more farmers use improved seed, especially hybrid sunflower seed imported from India (Isinika and Mwajombe 2019) and, more recently, from locally produced hybrid sunflower seed (Dalberg 2019).

Such reported trends have sometimes been difficult to verify because there is wide variation of production data from Tanzania. Data from the Ministry of Agriculture tend to be pessimistic while estimates from the Food and Agriculture Organization of the United Nations tend to be more optimistic (Selemani 2018). According to government estimates, by 2015, Tanzania produced about 2.8 million t (BOT 2017). Production is expected to grow further because there is a huge potential for growth driven by high demand of sunflower oil, available land for area expansion and favourable government policies to support sunflower production and processing (BOT 2017). As production increased, processing capacity has increased at a faster rate, hence, processors face challenges in obtaining sunflower seed, with their machines often operating below their installed capacity.

Small processors also have to compete for seed with large processors which has, at times, driven the price up to unsustainable levels. Meanwhile, power outage reduced capacity utilisation (BOT 2017). Large processors have sometimes resorted to imported seed from neighbouring countries (Burundi, Malawi, Rwanda and Uganda), which has been cheaper than locally produced seed during some years (Dalberg 2019). Locally produced sunflower seed is deemed to be relatively expensive due to low productivity by most farmers, the national yield average is estimated at 0.6t/ ha) (BOT 2017). Processors also face unreliable supply due to fluctuating weather as drought has become more recurrent, but farmers also tend to switch to alternative crops such as maize, green gram or chick peas, in response to changing relative prices (Isinika et al. 2020). The combined impact of rural electrification, which increased sunflower processing and relatively better prices for sunflower seeds have in most cases benefited the well-off households as they were able to respond to some new opportunities, such as increased production, through use of animal drawn technology (ADT) and hired labourers.

\subsection{The role of imports and exports}

Tanzania's demand for edible oil was estimated at 570,000 t per annum in 2018, and is projected to grow to $700,000 t$ by 2030 . Local production only meets about 30-45 per cent of the demand. Thus, the country imports nearly 320,000t annually, worth over US\$83 million (Food Business Africa 2018). Imports of crude edible oil have been increasing annually reaching 500,000 in 2015 (Figure 3.3). Crude palm oil dominates the volume of imports, accounting for about 44 per cent during 2015 (BOT 2017) mostly coming from Singapore and Indonesia. Other imports of edible oil include olive oil, vegetable oil and sesame. Tanzania also imports a small proportion of sunflower oil, accounting for 1.7 per cent in 2015.

The country also exports sunflower products (seed, oil and seed cake), which were valued at about US\$74.9 million by 2014 . Of these, seed cake is the most 
Table 3.1: Sunflower seed, oil and cake exports (,000 US\$): 2005-2016

\begin{tabular}{|l|l|l|l|l|l|l|l|l|l|l|l|l|}
\hline Product & 2005 & 2006 & 2007 & 2008 & 2009 & 2010 & 2011 & 2012 & 2013 & 2014 & 2015 & 2016 \\
\hline $\begin{array}{l}\text { Sunflower } \\
\text { seed }\end{array}$ & 0.1 & 0.2 & 1.0 & 1.4 & 0.1 & 0.1 & 0.1 & 1.6 & 1.7 & 0.3 & 0.0 & 0.5 \\
\hline $\begin{array}{l}\text { Crude } \\
\text { sunflower oil }\end{array}$ & 0.0 & 0.3 & 0.2 & 4.8 & 2.0 & 12.4 & 12.9 & 12.7 & 6.2 & 7.1 & 6.3 & 0.2 \\
\hline $\begin{array}{l}\text { Refined } \\
\text { sunflower oil }\end{array}$ & 1.8 & 0.4 & 0.4 & 1.8 & 1.0 & 2.3 & 1.4 & 0.7 & 0.9 & 1.9 & 0.6 & 0.4 \\
\hline $\begin{array}{l}\text { Sunflower } \\
\text { seed oil } \\
\text { cake }\end{array}$ & 0.1 & 0.0 & 0.2 & 11.1 & 11.9 & 8.3 & 7.5 & 45.0 & 24.9 & 65.6 & 7.0 & 20.5 \\
\hline
\end{tabular}

Source: UN Comtrade Database cited by Balchin et al. (2018)

Figure 3.3: Total imports of crude edible oil to Tanzania: 2012-2015

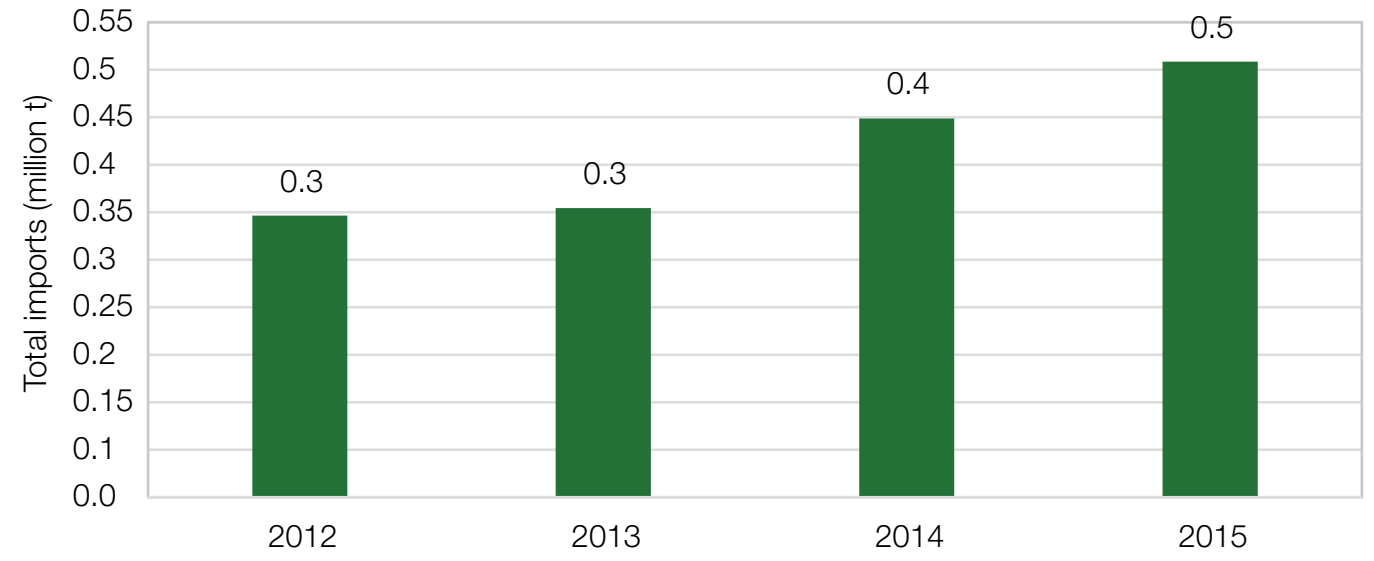

Source: BOT 2017

dominant, accounting for nearly 88 per cent of the export value (Table 3.1). India is the leading importer, taking about 82 per cent of the sunflower exports from Tanzania, followed by Kenya (5 per cent), Switzerland (5 per cent) (BOT 2017). 


\section{MAPPING THE SUNFLOWER SUBSECTOR IN TANZANIA}

\subsection{The market map}

In a value chain context, actors are those who produce or transact in a product, ranging from primary producers up to the final consumers. The sunflower subsector has two main value chains, sunflower oil and sunflower cake. The other value chains (sunflower seed and oil) have accounted for less than 25 per cent of the exports on average since 2012 (Table 4.1). The main actors in the sunflower value chains include farmers, traders, processors and consumers. These are facilitated by various service providers who include input suppliers, particularly seed, fertiliser and pesticides. Agricultural research institutions and extension services, provide information and coordination for improving husbandry, and hence productivity as well, improving market coordination. Processors stand out as pivotal service providers for milling and warehouse services, but they also serve as value chain actors since they buy seed for processing. Additional service providers include financial services, transporters and many others, as presented in Figures 4.1, 4.2 and 4.3.
Coordination of the sunflower sector is mainly provided by two ministries; the Ministry of Agriculture ${ }^{1}$ and Ministry of Trade and Investment (MITI). The former addresses production, marketing and processing, while the latter centres on issues related to standards for processed products, imports and exports. A number of agencies fall under each ministry to provide policy guidance and regulations. Government institutions address issues related to the policy and institutional framework while private sector networks, associations and NGOs work with the government to improve the policy environment, using different strategies to lobby and advocate on behalf of actors in the chain.

\subsection{Relations within the sunflower value chain}

\subsubsection{Production}

Sunflower production is dominated by smallholder farmers who account for nearly 95 per cent of all the producers, cultivating 2 ha or less, 4 per cent are medium (5-100ha) and only 1 per cent are large,

Figure 4.1: General sunflower sector value chain: Tanzania

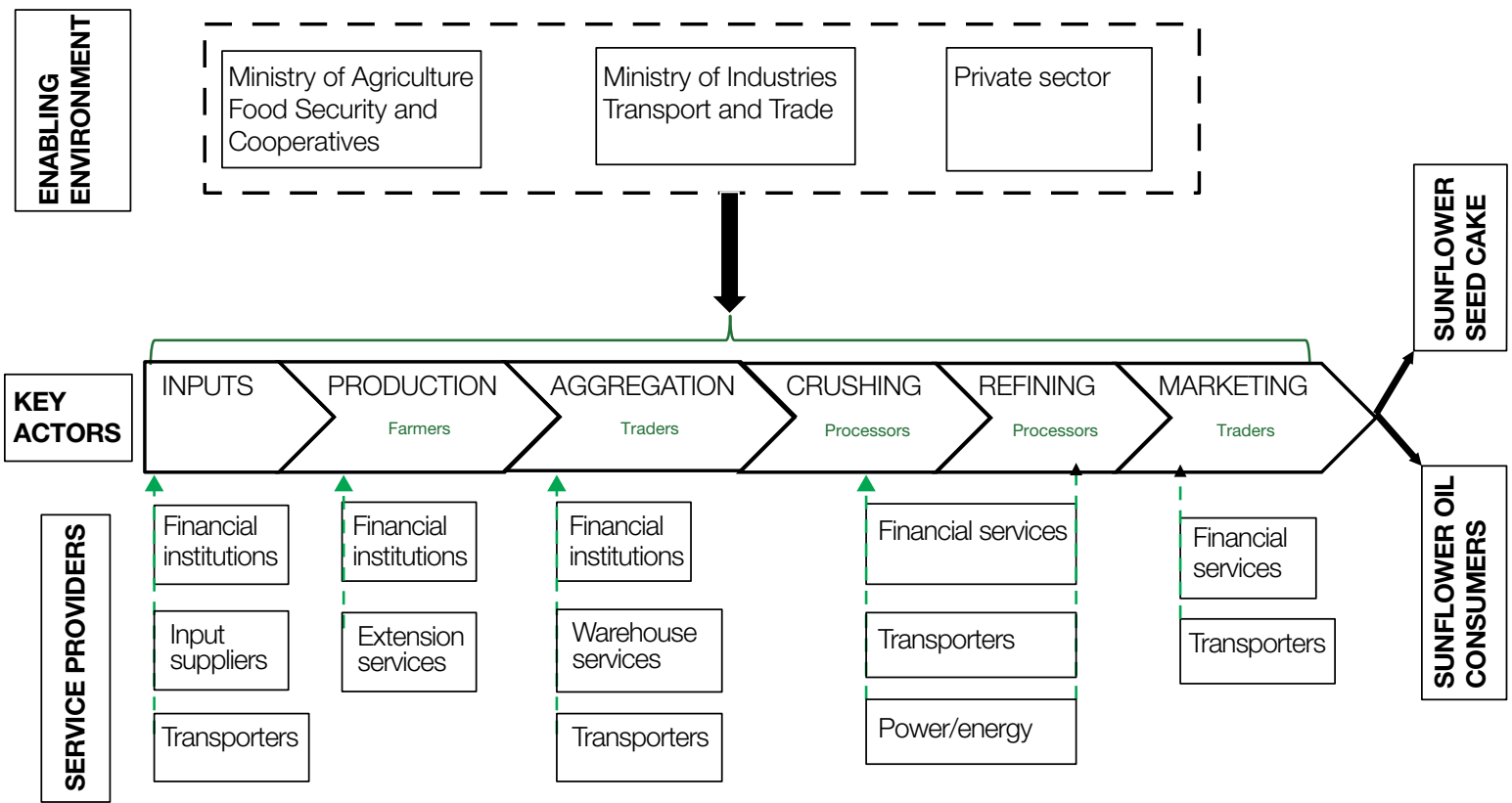

Source: Adapted from Dalberg (2019) 


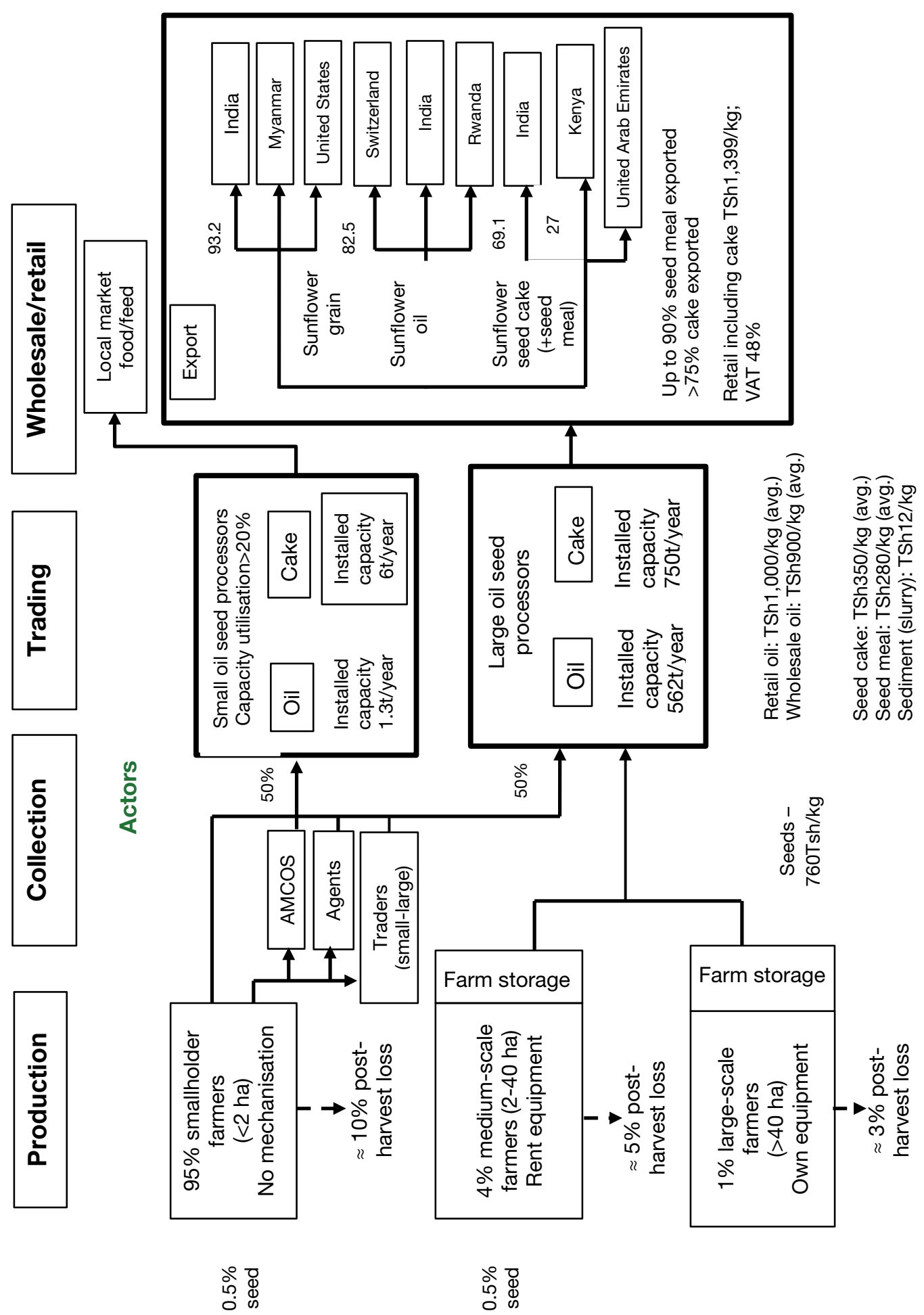

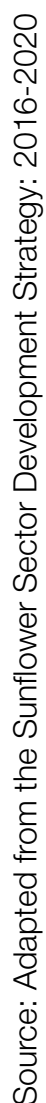


Figure 4.3: Enabling environment and service providers

\begin{tabular}{|c|c|}
\hline Ministry of Agriculture & Ministry for Trade and Investment \\
\hline Tanzania Official Seed Certification Institute & Tanzania Trade Development Authority \\
\hline Agricultural Seed Agency & Export Processing Zone Authority \\
\hline Agricultural research institutes & National Development Corporation \\
\hline Tanzania Fertilizer Regulatory Authority & SIDO \\
\hline Department of Research and Development & Tanzania Industrial Research and Development \\
\hline District Agricultural, Inputs and Cooperatives Officer & CARMATEC \\
\hline TCCIA & Private sector and NGOs \\
\hline Tanzania Exporters Association & Dodoma Agricultural Seed Producers Association \\
\hline Confederation of Tanzania Industries & Tanzania Seed Trading Association \\
\hline East Africa Grain Council & Agricultural Council of Tanzania \\
\hline Tanzania Edible Oil Seeds Association & Tanzania Agricultural Development Bank (TADB) \\
\hline TASUPA & Mtandao wa Vikundi vya Wakulima Tanzania \\
\hline
\end{tabular}

Source: Adapted from URT (2016)

cultivating over 40ha (URT 2016). A household survey in Iramba and Mkalama districts, Singida Region involving 601 farmers, classified farmers according to farm size. In this survey, 82.3 per cent were classified as small, 17.4 per cent were medium and only 0.3 per cent were classified as large (Isinika et al. 2020). The distribution of total land was skewed by gender, farm size and wealth status. Male-headed households (MHHs) owned significantly more land than $\mathrm{FHHs}$, and so did large and medium-scale farmers compared to small farmers when classified by farm size. Likewise, rich farmers owned significantly more land than poor farmers (Figure 4.4). In addition, the proportion of women among the lower ranks (small and poor farmers) is a greater number when compared to those among higher ranks (medium and rich farmers). Subjective wealth ranking by farmers in the same study classified 15.3 per cent of the households as rich, 35.9 per cent as middle and 48.8 per cent as poor. A qualitative study under the same study (Isinika and Mwajombe 2019) similarly showed that out of 963 farmers smallholders represented 59 per cent of the sample followed by middle (30 per cent) and high-ranking farmers (11 per cent). Classification into these categories was based on local accepted criteria as presented in Appendix 3. These are correlated with household classification by farm size.

Figure 4.4: Total land owned by different categories of farmers in Iramba and Mkalama districts

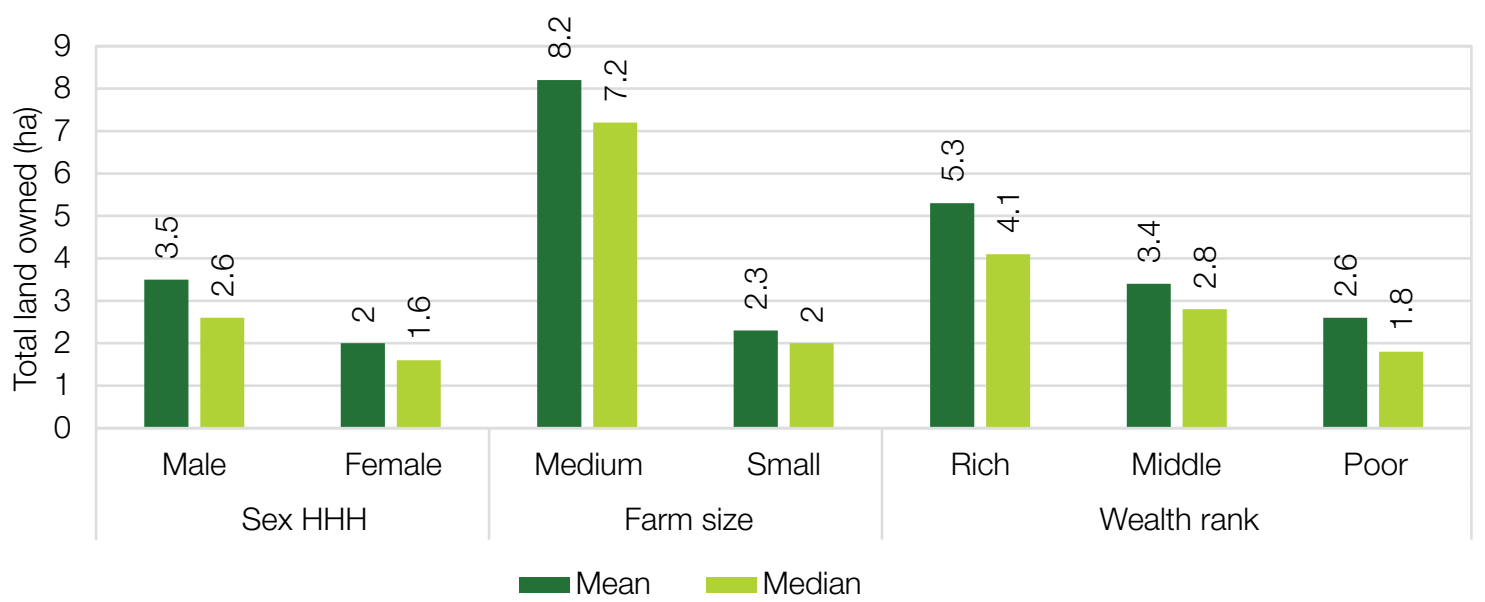

Source: APRA Tanzania survey (2019) 
The majority of sunflower farmers should be expected to be male since, according to the last national census (2012), FHHs account for about 34 per cent of all the households (URT 2013), but a lower figure among the rural population. A study in Singida Region similarly established that 79 per cent of the sunflower farmers were male (Zilihona 2013). Another study in Mkalama and Iramba (Mdoe et al. forthcoming) shows that nearly 14 per cent of the respondents in a household survey were female-headed, which is lower than the national average. All the ethnic groups in these districts (Wanyaturu, Wanyiramba, and Wasukuma among others) are patrilineal hence land is predominantly acquired by inheritance through the male lineage (Isinika and Mwajombe 2019). This is also true in many other parts of Tanzania (Isinika and Mtabazi 2010; Koda 2000).

Acquisition of land via purchase from land markets is however gaining prominence as the land frontier for allocation by village leaders gets exhausted and more land shifts from customary to statutory tenure via ownership formalisation (Isinika et al. 2019). The study in Mkalama and Iramba District showed that only 5.9 per cent of the respondents acquired land by allocation from local government and traditional leaders (Mdoe et al. forthcoming). Women's rights to own land while assured under statutory low they are limited by customary land tenure practices, which also applies under the dual land tenure system operating in Tanzania. FHHs also face income constraints to acquire land via markets. However, among the Wanyiramba and Wasukuma ethnic groups, married women have some customary rights to own small a piece of land, which may be allocated to a wife by her husband. In some villages, women groups have used such customary rights and their ability to organise in groups, to enhance their rights within the sunflower value chain (Mosha et al. forthcoming).

The majority of sunflower farmers cultivate small farms ( $<2$ ha) while use of improved inputs (seed and fertiliser) is low, but the region has many livestock, hence some farmers use organic manure (Mdoe et al. forthcoming). For example, while it was found that the use of improved seeds and early planting were important for increased productivity, majority of women and $\mathrm{FHHs}$ could not afford the prices of improved seeds. Consequently, there was a big gender disparity with regard to purchase and use of the improved sunflower seeds since 87.2 per cent of $\mathrm{MHH}$ used improved seed as compared to only 12.4 per cent of the FHHs. Tillage is often by ADT, especially in Singida and Dodoma, the leading sunflower producing regions. Analysis from Iramba and Mkalam districts involving 601 farmers showed that 89 per cent used ADT while 11 per cent used tractors for cultivation (Isinika and Mwajombe 2019). Nonetheless, tillage using the hand hoe is still common, especially among poor families and for weeding, when nearly all farmers employ hand weeding by hoe. Respondents from a household survey in the same study revealed that the proportion of $\mathrm{FHHs}$ using hand hoes for tillage is higher (89.7 per cent) compared their male counterparts (10.3 per cent) (Mdoe et al. forthcoming).

Using oxen for land preparation has enabled farmers to cultivate larger areas than they would achieve using hand hoes. Such expansion however, has in most cases led to competition among farm enterprises especially for land and labour. Labour becomes particularly limiting during critical periods of planting and weeding. While there are some local variations on how labour is organised for sunflower production and marketing with implications on social difference, in most regions, the majority of farmers use family labour, complemented with hired labour. Again, lessons from Singida Region provide insights on how labour is organised. Medium and large-scale farmers hire additional labour mostly for weeding. Poor farmers begin the farming season by selling their labour in order to get cash for buying seed and hiring tillage services. Hence their own farm operations are delayed. They plant late leading to low yields, which makes it difficult for them to close the social differentiation gap, thereby widening the gap even further (Isinika and Mwajombe 2019).

The availability and productivity of labour determines who reaps the benefit of the commercialisation. In the context of sunflower commercialisation in Singida Region, relatively poor households and women benefit less from sunflower commercialisation compared to the rich and $\mathrm{MHHs}$. Within most households, men benefit more compared to women, since men control the use of proceeds from sunflower sales.

\subsubsection{Enabling institutions and service providers}

Government extension services promote high productivity among smallholder farmers through training and coordination of input and product markets. Various development agencies have also been promoting sunflower production for livelihood improvement (income and nutrition). Most of the early support during the 1980s and 1990s was directed at women groups to improve processing, as traditionally, women were responsible for processing sunflower at the household level, as alluded to earlier. As commercialisation increased and men took the lead in post-harvest handling and marketing, support from the government and NGOs has been directed to all farmers, sometimes with emphasis on gender inclusion under the broader focus on poverty reduction. For example, the Netherlands Development Organisation (SNV) has been supporting the oilseed 
sector since 2007, aiming to increase the income of at least 120,000 among sunflower farmers in the country by at least 50 per cent. Under their current programme (2017-2020) SNV is reaching about 21,000 farmers. Another programme by the Agricultural Marketing Development Trust over a five-year period (2016-2021) plans to raise the incomes of at least 150,000 farmers by improving seed access. Other partners which have supported the sunflower sector include FAIDA MALI; a local NGO; Rural Livelihoods Development Company (RLDC); International Fund for Agriculture Development, Marketing Infrastructure, Value Addition and Rural Finance Support Programme; Farm Concern; One Acre Fund Tanzania and many others (Dalberg 2019).

Low use of improved inputs has been a major bottleneck for developing the sunflower sector. The use of improved sunflower seed has been especially low due to limited availability and affordability. Hybrid seed imported from India since 2014 has been too expensive for most farmers. To address these problems, the government has been working with the private sector and development agencies to increase the supply of affordable hybrid seed, whose yield is typically $5-8 \mathrm{t} / \mathrm{ha}$, and the oil content is higher (43-48 per cent). In 2018/19, the government approved the Seed Registration and Financing Act, which among other things, provided for fast-tracking the registration of hybrid seed for use in Tanzania. Since then, private investment in seed multiplication has increased, and more than ten new locally-bred hybrid seed have been released, and the price of high-yielding hybrid sunflower seed has been reduced by about 60 per cent from TSh70,000/kg to TSh30,000/kg (Dalberg 2019). Increasing use of hybrid seed, coupled with improved agronomic practices, are expected to double production without increasing the acreage. Such efforts will meet the needs of processors, whose capacity and efficiency are also set to increase.

\subsubsection{Marketing sunflower seed}

The smallholder farmers experienced about 10 per cent post-harvest loss and they retain about 0.5 per cent of their harvest for domestic consumption and for seed. About half of their production is processed by small oil seed processors, normally close to their villages while the other half is processed by large processors (Figure 3.2; URT 2016). Sunflower seed is marketed through three main channels. Under the first channel, farmers sell raw sunflower seed directly to processors, who then sell their processed products through traders to the ultimate consumers of sunflower oils. The second channel involves sale of raw sunflower seed through traders, who then sell to processors. Thereafter, the processors sell the processed products directly to ultimate consumers of sunflower oils. The third channel involves the sale of raw sunflower seed through traders, who then use the processors' services. However, the traders retain ownership of the products, especially oil, which they sell to wholesalers and ultimate consumers of sunflower oils: a similar trend applies for sunflower seed cake (Zilihona et al. 2013). Most of the marketing transaction arrangements for sunflower farmers are based on trust. There are no formal contracts between farmers, traders and processors. The actors at the marketing and processing nodes are predominantly male, but the beneficiaries or users of such services involve both men and women farmers.

The large processors also have their own agents for buying seed. Large traders normally have aggregators at the village level. These are villagers, often middle-aged, and of middle- or high-wealth rank, aspiring to be (or in the stage of becoming) larger traders. Most of them are male, because the task involves travelling around villages, often by bicycle or motorcycle. Aggregators provide credit to farmers during the lean months (December-February) to be paid in kind during harvest. Such funds often come from larger traders operating in urban areas. Where cooperatives are functioning, some farmers sell sunflower seed through Agricultural Marketing and Cooperative Societies (AMCOS), but these are not common. Recently, the local government authority in Singida Region has proposed the use of warehouses receipt system to improve the marketing arrangements with smallholder farmers and hence, increase their profit margin by avoiding excessive brokerage along the marketing chain. This is in line with the guidance of the sunflower sector development strategy for Tanzania where collective marketing is proposed as one of the options that can increase returns to small holder farmers (URT 2016). However, lack of storage facilities and weak AMCOS to facilitate implementation of the warehouse receipt system remains a real challenge in many parts of Tanzania.

\subsubsection{Processing}

In Tanzania, medium-scale farmers account for only 4 per cent of all the sunflower farmers, cultivating around 2-40ha (URT 2016), with some renting equipment for farm operation. They retain about 0.5 per cent of the sunflower seed for domestic consumption and experience about 5 per cent post-harvest loss, and their entire production is processed at large processors. Large-scale farmers who cultivate more than 40ha only account for 1 per cent of all farmers. Their postharvest loss is only 3 per cent, much lower compared to smallholder farmers since most of their operations are mechanised. Their entire production is processed by large processors (URT 2016).

Sunflower value addition takes the form of crushing the seed to extract oil but also obtain seed cake, seed meal and slurry. Processors have three options, (a) crush the 
seed to extract oil without refining, (b) crush the seed and complete the first refining, and (c) crush the seed and complete the first and second refining to produce what is commonly known as double-refined oil. There are small, medium and large processors. A study of forty processors in Iramba and Mkalama districts (Magomba and Gideon 2020) showed that 30 (75 per cent) were small, while the remaining were medium. While each of the small processors employed less people on average (7.4 men and 3.1 women as casual labourers, 1.3 men and 0.5 women as permanent employees), the employment effect is stronger from small processors due to their large number.

By 2014, small processers had an installed capacity to produce up to 1.3t/year and 6t/year oil and seed cake respectively. They take up about 50 per cent of the sunflower seed from smallholder farmers. Large and medium processors had an installed capacity estimated at 562t/year for oil and 750t/year for seed cake. They process about 50 per cent of the seed from smallholder farmers and all the seed from medium and large farmers. Sometimes, they also import seed for processing. Most small and medium processing reaches only about 45 per cent utilisation capacity in-season (May-October), and lowers to only 5 per cent during off-season (November-April) (Dalberg 2019). Other estimates put the capacity utilisation of small processors at only 20 per cent, while that of large processors is estimated between 25 and 40 per cent (URT 2016).

Analysis has shown that the main bottleneck to sunflower industrialisation in Tanzania is the use of inefficient processing technology (URT 2016). There are two methods of extracting sunflower oil from seed: mechanical and solvent extraction. Mechanical methods can extract only up to 80 per cent of the oil, with the remaining 20 per cent being extracted at large processors using the solvent method (Dalberg 2019), where hexane or other organic solvents are used to extract the remaining oil in the pressed seed cake without increasing the temperature to damaging levels. Investment in processing has increased, but many investors still opt for mechanical extraction that is less efficient, due to affordability and availability in the local market. By 2014, only two plants in the country were using the solvent method (URT 2016). Records also show that by 2014, there were over 1,000 sunflower oil processors in Tanzania, but most of these were smallor medium-scale, using the crushing extraction method (usually Chinese or Indian technology), which are readily available in the local market. Most of the new investors have located in the Central and Lake Zone, which are the leading sunflower production areas in the country (Appendix 1).
The government has, since 2018/19, removed valueadded tax (VAT) on solvent extraction machinery and sunflower by-products such as seed cake. Meanwhile, import duty on palm oil (crude and refined) has been increased in order to promote the local sunflower oil sector. Such protection from subsidised palm oil imports has encouraged entry of medium and large processors (local and foreign), who use solvent technology and some of the existing medium and large firms plan to expand to solvent technology (Dalberg 2019). To cope with the shortage of sunflower seed for processing, some of the large investors are using contract farming. For example, the PYXUS firm based in Dodoma has a network of 10,000 contract farmers, to whom they offer extension services, agronomy support, and premium price for quality seed based on oil content. This encourages farmers to use hybrid seed, which has higher oil content.

Some of the large processors had received VAT exemption during the investment phase, prior to 2016, raising complaints from competitors (medium and small processors). However, such VAT exemption is scheduled to expire in 2020 (Dalberg 2019). Although the exemption period has already expired, VAT on imported agricultural machinery has remained zerorated since 2016. However, this does not apply to importing traders who sell in the local market, or for locally produced processing machinery. These are commonly purchased by the majority of small processors. $^{2}$

Another area of concern has been the problem of excessive taxes and fees in the sector, which affects the ability of traders and small processors to compete, thereby reducing the farm gate price payable to farmers. Multiple taxation from different government institutions has been a long-standing concern of processors in the country, although the Government is working to address these challenges. For instance, crop cess taxation has been reduced from 5 to 2 per cent (Dalberg 2019).

\subsubsection{Markets for sunflower products}

About 50 per cent of the seed from smallholder farmers is processed by small processors to produce unrefined oil and seed cake. Slurry is less important, but it does provide some employment, especially to women who buy it from the mill owners for further oil extraction by boiling. While some of the cake and oil from small processors is bought by large processors for further processing, most of these products go into the local market, the oil for domestic consumption, while the cake goes for animal feed. There is demand in the local market for the semi-refined oil, which is also cheaper (Balchin et al. 2018). However, this market 
Table 4.1: Tanzania export of sunflower products (US\$ millions)

\begin{tabular}{|l|l|l|l|l|l|l|l|l|l|l|l|l|}
\hline Product & 2005 & 2006 & 2007 & 2008 & 2009 & 2010 & 2011 & 2012 & 2013 & 2014 & 2015 & 2016 \\
\hline $\begin{array}{l}\text { Sunflower } \\
\text { seeds }\end{array}$ & 0.1 & 0.2 & 1 & 1.4 & 0.1 & 0.1 & 0.1 & 1.6 & 1.7 & 0.3 & 0.0 & 0.5 \\
\hline $\begin{array}{l}\text { Crude } \\
\text { sunflower oil }\end{array}$ & 0.0 & 0.3 & 0.2 & 4.8 & 2.0 & 12.4 & 12.9 & 12.7 & 6.2 & 7.1 & 6.3 & 0.2 \\
\hline $\begin{array}{l}\text { Refined } \\
\text { sunflower oil }\end{array}$ & 1.8 & 0.4 & 0.4 & 1.8 & 1.0 & 2.3 & 1.4 & 0.7 & 0.9 & 1.9 & 0.6 & 0.4 \\
\hline $\begin{array}{l}\text { Sunflower } \\
\text { seed oil cake }\end{array}$ & 0.1 & 0.0 & 0.2 & 11.1 & 11.9 & 8.3 & 7.5 & 45.0 & 24.9 & 65.6 & 7.0 & 20.5 \\
\hline
\end{tabular}

Source: Balchin et al. (2018) citing UN Comtrade Database

faces serious quality challenges, and poor or a lack of branding. The quality of sunflower oil sold by the roadside in most of the sunflower producing regions is most likely compromised due to prolonged exposure to sunlight, but there is little consumer awareness about such quality and health effects (URT 2016). In Tanzania processed food products are certified by the National Bureau of Standards (NBS) and the Tanzania Food and Drugs Authority. All of the oil sold by the roadside, however, lacks certification from these national bodies, probably because these institutions do not have the capacity to enforce the law to roadside vendors across the country.

Expansion of sunflower production has also led to growth of exported sunflower products (seed, oil and cake). The value of sunflower products increased by 70 per cent between 2005 and 2014 rising from US\$1 to US $\$ 70$ million (MITI cited by Balchin et al. 2018). The rise in exports has mostly been driven by seed cake which has found new markets in India and other countries (Figure 3.3). The value of exports since 2005 is presented in Table 3.1. Sunflower oil exports, however, face challenges of price competitiveness due to high production cost, largely attributed to expensive locally sourced sunflower seed, making sunflower oil from Tanzania uncompetitive in international markets. It has been reported that by 2013, imported crude sunflower oil was marginally cheaper at US\$1,036/million t free on board, compared to 1,211 /million $t$ during the low season and US\$1,036/million $\mathrm{t}$ in the high season (URT 2016).

Meanwhile, export of sunflower seed is very low and declining due to increasing local processing capacity and higher tariffs on exported seed (Chisoro-Dube et al. 2018). About 82.5 per cent of refined oil goes to Switzerland for the confectionery industry. Within the region, Kenya is the leading importer of sunflower seed cake while Rwanda is the top importer sunflower oil from Tanzania (Figure 3.3). In light of all these opportunities and challenges facing the sunflower sector, the Government has been making various measures to improve the sector's performance in terms of productivity and competitiveness in local and export markets. 


\section{POLICIES AND STRATEGIES FOR GROWTH OF THE SUNFLOWER SUBSECTOR}

In previous sections, while discussing issues related to production, processing and marketing, reference has been made to some policies and strategies to enhance the sector performance. In this section, we observe such policies and strategies chronologically in order to reinforce the outcome of policy interventions, including the interactive effect across policies and the implication for future options. In this regard, we limit the discussion to the policy environment since 2014, which marked the end of the first Agricultural Sector Development Programme, implemented from 2005. Some of the recent interventions to promote sunflower industrialisation have included:

- 2014: The raw seed export tariff. Imposing a 10 per cent tariff on export of raw sunflower seed in order to promote local value addition and industrial growth.

- 2016: The National Sunflower Sector Strategy. Designed to transform the sunflower sector through coordinated intervention by improving production, processing and marketing in local, regional and international markets.

- 2018/19: A number of policy changes have taken place implementing the sector strategy. These include:

- Removal of VAT on solvent extraction machinery to attract more investors.

- Removal of VAT on sunflower products (seed cake) to promote export.

- Increase of duty on oil palm imports, from 10 per cent to 25 per cent for crude oil palm and from 25 to 35 per cent for refined palm oil. This is designed to protect and promote the local sunflower oil sector.

- Meanwhile, efforts are also on-going to increase local production of palm oil by area expansion and improving processing efficiency.

- Inputs (Seed Registration and Financing Act of 2019). This has enabled fast tracking of hybrid sunflower seed registration resulting more than ten new varieties being introduced. More private sector and government institutions are now involved in producing hybrid seed.

- Introducing irrigation for sunflower has been suggested to increase local production of sunflower seed (Dalberg 2019).

These government efforts to improve the policy and business environment, ranging from increased supply of hybrid seed to improved processing efficiency, were expected to deliver positive impacts throughout the value chain (Dalberg 2019). Most of the policy initiatives have had the expected outcomes, but some outcomes have been marginal at best, or even negative. Production of cheaper locally-produced hybrid seed has increased. Already, more than ten different varieties of improved hybrid seed are in the market, reducing the price by 57 per cent compared to imported hybrids. The adoption of hybrid seed is increasing due to higher yields and higher oil content. In Iramba District, for example, the proportion of farmers using hybrid seed has risen from about 15 per cent in 2016/17 to 45 per cent in 2019/20 (personal communication with Iramba District crops officer). Such adoption should increase as farmers' access to financial services improves. The TADB has established a credit guarantee scheme covering all crops, including sunflower, but this initiative faces challenges as bankers choose to lend to more established crops (e.g. cotton, coffee, cashew, sugarcane). Meanwhile, many farmer groups fail to access credit and loans through AMCOS due to lack of regulation in the sector (Dalberg 2019).

Despite various well-intended government policies, the effect of increased tariffs on imported crude palm oil seems to bring mixed results. A study by Balchin et al. (2018) revealed contrasting views among stakeholders in the sector regarding the tariff. Private sector associations such as TASUPA (representing processors), and TCCIA (representing businesses) support the tariff on edible oil imports for the benefit of local farmers and small-scale processors. However, large processors and well-established wholesalers are not in favour, believing that the tariff has failed to stimulate local production and lower the farm gate price of sunflower seed as planned. This argument may be premature, as local production of hybrid sunflower seed was used by farmers for the first time during the 2019/20 season. Others argue that 
raising the price of palm oil, which meets more than half of the local demand, only hurts low-income local consumers. In any case, falling world price of crude palm oil (CPO) still makes imported palm oil cheaper.

The political economy of the edible oil sector in Tanzania is thus characterised by the struggle of competing groups to influence policy in their favour: small- and medium-scale versus large-scale processors on one side, and sunflower processors and CPO importers on the other. A recent exchange in the media reflects the intent of CPO importers to maintain their market share. They alleged that there was a serious shortage of edible oil in the country, but TASUPA quickly refuted the allegation. The edible oil sector also suffers from lack of transparency, particularly from importers, processors and distributors of palm oil. Studies by Dalberg (2019) and Balchin et al. (2018) point out a number of anomalies in this regard:

When the tariff on CPO was raised from 10-25 per cent between June and July 2018 importers immediately switched to importing refined palm oil. But other stakeholders argue that what was previously reported as imported as CPO, was already refined palm oil.

There was a high spike in the import of refined palm oil in May and June 2018, just before the new tariff structure came into effect in July.

Stakeholders highlight that the tariff on CPO may increase smuggling of palm oil products from neighbouring countries. This is particularly attractive now that the world price of palm oil has been falling, as stated earlier.

Overall, the impact of changing the tariff structure on imported oil is mixed. On a positive note, government tax revenue has increased, but, it may be too early to observe the extent of other outcomes. For instance, farmers' production response switching from using local varieties to locally-bred hybrid seed may take at least three to four years to become significantly noticeable. Meanwhile, some negative collateral damage has been expressed by local soap processors, who cannot compete for seed cake with exporters. Consequently, the import of soap is rising (Dalberg 2019; Balchin et al. 2018). These lessons inform stakeholders in the value chain on how to improve the proposed strategy for transforming the sunflower sector (URT 2019) by implementing six strategic objectives. 


\section{SOCIAL DIFFERENCE WITHIN THE SUNFLOWER VALUE CHAIN}

The analysis and discussion of social differentiation focused on identifying actors along the value chain in the commercialisation process, spanning from the international to the national, and the community down to the intra-household level. The groups included gender, marital status, age and generation, wealth groups and ethnicity. The analysis and discussion focused on how commercialisation, or changes in the nature of commercialisation, has impacted on different groups. This includes the implications of labour organisation along the value chain, and the changing nature of access to resources to facilitate engagement in value chain activities. For example, how does group identity, (such as being a $\mathrm{FHH}$ or $\mathrm{MHH}$ ), livestock ownership, age, and ethnic identity influence land access for commercial production? Furthermore, how does it affect access to credit and services to facilitate engagement in various activities along the value chain? How has commercial agricultural production and changing income patterns impacted on food and nutritional food security at the household level, in view of changing food systems and consumption patterns? Can dominant labour organisations, such as cooperatives or producer groups, be identified? With whom do they interact? What market power relations are important under such interaction? (Blessing et al. 2020).

In this paper, social differentiation between groups (differentiated by sex, wealth rank, farm size, asset ownership, age and other categories) to identify interactions, and the outcome and impact of commercialisation processes. As discussed in Section 4.2.1, at the primary production-level farming households are predominantly male-headed, consistent with their proportion in the population. Most of them are small-scale, cultivating 2 ha or less, however, medium- and large-scale farmers own more total land, as do $\mathrm{MHHs}$, compared to their female counterparts. Likewise, rich- and middle-wealth ranked farmers own more total land relative to small and poor farmers.

In Section 1.2 we discussed how prior to commercialisation, women dominated processing of sunflower seed for household consumption and for sale of oil to neighbours in local markets. As men have taken over processing following commercialisation, there is a consensus that women have been relieved from the arduous task of oil-processing. However, evidence from the study area indicates that the takeover has also been disempowering to women, as families where there is disharmony, women have little or no say regarding the use of proceeds from the sale of sunflower seed, oil or seed cake. Such households also reported a higher proportion of livelihood decline because the spouses do not pursue commonly agreed enterprises. Women may even withhold their labour from cash crops such as sunflower, focusing instead on food crops, where they have more control.

Qualitative studies in Iramba and Mkalama in Singida Region (Isinika and Mwajombe 2019), revealed that changes in the level of wellbeing over time differed across wealth rank, gender and age, leading to social differentiation. For example, during the interval from 2010 to 2018, FHHs experienced a higher proportion of decline in wealth (31 per cent) compared to $\mathrm{MHHs}$ (17 per cent). A higher proportion of $\mathrm{FHHs}$ also remained unchanged (44 per cent) compared to their male counterparts (27 per cent). When the households were categorised into low, middle and high wealth rank according to locally agreed criteria (see Appendix 3), livelihood improvements was experienced by most of the high wealth ranked households. Meanwhile, only a modest proportion of households in the middle wealth rank experienced improvement, and instead a relatively high proportion stagnated or declined. The highest proportion of stagnating or declining livelihoods was experienced among low-ranking household, especially in Iramba District. Older household heads, both male and females also faced a higher risk of decline due to prolonged sickness and being widowed.

Meanwhile, sunflower commercialisation has changed the institutional framework for managing livestock reducing social differencing between wealth ranks. As sunflower commercialisation depleted land for grazing, owners of large herds have been forced to either migrate west into less densely populated districts (Ikungi and Manyoni) or they had to redistribute their herds to poor neighbours, relatives and friends as care takers. The redistribution of livestock among the caretakers, who are in most cases from very poor households, has reduced inequality by improving the nutrition of caretakers who use and even sell milk from the cattle 
they tend. They also benefit from using oxen services and manure, thereby expanding area under production and improving farm productivity. Such improvement may however not be strong enough to have an impact on their overall wealthy status since the livestock still belong to the owners. Nevertheless, improved farm productivity and the ability to cultivate larger areas using oxen, has enabled some of them to acquire their own livestock, and some have moved up a step in wealth. The new system of livestock management has therefore helped to close the social difference gap between livestock owners and caretakers. 


\subsection{The national response}

The COVID-19 pandemic which struck the world in 2020 also affected Tanzania. The effect of the pandemic, in terms of rising rates of infection and mortality, was evident in the country from around February/ March 2020. The government implemented restrictive measures to contain the infection from spreading and reduce the mortality rate. All schools and academic institutions were closed, and personal hygiene by regular handwashing, using sanitisers and wearing face masks was promoted, the latter being enforced in public places. Social distancing was required in all public places, sitting only became mandatory in public transport and people were advised to minimise social interaction to 50 people or less. Tanzania never had a lock down per se, businesses and religious services remained open while observing social distancing. Despite all of the measures put in place to address the pandemic, the global economic recession caused by preventative measures against the pandemic also affected Tanzania, causing an economic slowdown. Some businesses closed voluntarily for the safety of owners and employees.

Consequently, the demand of many goods and services declined, but others saw a rising demand. For example, people adopted alternative measures, such as steaming using herbs (used in the past for respiratory diseases), believing that it could prevent the COVID-19 virus. Also, various nutritional combinations were recommended, and many were highly shared via social media. This increased the demand for ingredients of such recipes, including: lemon, oranges, onions, garlic, ginger, pepper and cardamom. Interviews with about 20 stakeholders in the sunflower value chain, mainly from Singida Region, revealed that all of them were aware of the guidelines issued by the Ministry of Health. According to village leaders and farmers who were interviewed by phone as well as through focus group discussion in a study on climate change in the same area (Mutabazi and Gideon forthcoming), there was no case of COVID-19 in all the villages where the respondents lived.

\subsection{Pandemic effects on sunflower production and marketing}

All the respondents noted that by the time the coronavirus pandemic arrived in Tanzania (around March 2020), sunflower had, in most parts of the country, been planted or in the process of being planted. As such, the pandemic did not have any impact on sunflower production. They noted, however, that sunflower production challenges during this year were due to excessive rains, such that sunflower seed from the crop which was planted early (January and February 2020), had produced lighter sunflower seed with less oil content. Traders are therefore paying a lower price. Several of the farmers who were interviewed noted that, around May 2020, a bag of sunflower seed (65-70kg) sold at TSh25,000-35,000, which was low compared to TSh43,000-55,000 around the same time in 2019. The reported lower price is also the result of fewer traders travelling to villages to buy sunflower seed, hence less competition among traders. In one village, a farmer reported that in 2020 they only had one trader visit per week compared to four or more in 2019. Likewise, respondents to an interview by mobile phone stated that fewer farmers travelled to urban centres to deliver sunflower to mills for processing, for fear of contracting the virus, which was reported to be present in urban centres such as Singida town.

During the interval February-April 2020, rural roads were also disrupted by excessive rains but remained passable since bad spots were repaired. In some routes, bus fares rose due to the requirement of sitting only for passengers. It was also reported that the number of truck and bus drivers who stopped by the road to buy sunflower oil declined due to fear of COVID 19, reducing daily sales of the road side hawkers. It is expected that the price of sunflower seed will improve, since most economic activities have picked up, as the Government is encouraging people to continue with their business while observing guidelines for COVID-19 issued by the Ministry of Health. Colleges and universities were opened in June 2020, while primary and secondary schools followed in July along with all other restricted 
economic activities such as local pubs and markets. More traders were expected to visit villages to buy sunflower seed.

\subsection{Sunflower seed cake}

The price of sunflower seed cake has also been affected due to reduced flow of cargo trucks into neighbouring countries, especially Kenya, a major importer of sunflower seed cake. Since Tanzania did not enforce a lockdown or conduct widespread testing, neighbouring countries have been cautious to allow traffic from Tanzania. Virus checks on truck drivers have slowed down the uptake of sunflower seed cake from processors, who also reported to be missing interest free credit, usually supplied by traders from Kenya, prior to collecting their stock of seed cake. Thus, the price of seed cake, which sold for up to TSh300-350/kg in May 2019, had declined to TSh250/kg in 2020. The largest share of sunflower seed cake is exported to India. The future of such exports, as well as the export of refined oil beyond Tanzania's immediate neighbours awaits, is dependent on the situation regarding maritime transport. Some processors already felt the impact of COVID-19 related trade restrictions, reporting the accumulation of sunflower seed cake in their limited warehouse space due to slow export uptake.

\subsection{Food security}

Respondents to the interviews had mixed views about their food security status. First, yields and production of food and cash crops has somehow been reduced due to excessive rain. Households with small farms may face food shortage. Consequently, many farmers have coped by switching to alternative income generating activities (IGAs) such as the production of onions, maize (sold fresh for roasting) and chick peas, all these under "irrigation" near river beds. More farmers can engage in this type of production during 2020 since water is more readily available, but this option is not available to everybody. The farmers who produced onions have actually benefited from the COVID-19 pandemic because the price of onions since March has more than quadrupled from TSh50,000 per bag $(100 \mathrm{~kg})$ in 2019 around April-May, to TSh250,000/bag in 2020 due to the increased demand. Onions were highly promoted via social media as an alleged remedy for mild COVID-19 cases. Respondents by mobile phone indicated that in Singida Region, farmers normally cope with reduced crop production by selling livestock. However, closure of livestock markets since March 2020 and the reduced number of traders visiting villages significantly reduced livestock prices, hence reducing the farmers' cash income. For example, the price of cattle declined from TSh700,000-1,000,000 in 2019 to TSh300,000-500,000 in 2020. Likewise, the price of goats has declined from TSh70,000-80,000 in 2019 to TSh40,000-50,000 in 2020, representing a significant decline in purchasing power for food normally obtained from the market. 
The analysis presented in this paper shows that sunflower production has expanded at the rate of 2.5 per cent per annum since 2010 in response to growing urban demand for sunflower oil and export demand for sunflower seed cake (Balchin 2018). This encouraged smallholder farmers, who constitute about 95 per cent of all sunflower farmers, to expand their planted area. In addition, an increasing number of farmers are adopting higher-yielding hybrid seed following government efforts since 2016 to increase the availability of such seed to boost local production. Improved farm productivity is expected to feed the expanding processing capacity, which is still dominated by small and medium-scale processors use the crushing extraction method. However, tax incentives are expected to attract more investors using the solvent technology, which is more efficient. The Government's recent initiatives aim to improve productivity, but these require time for the production response to become sustainable, owing to managerial and technical challenges mentioned previously. So far, farmers' supply response has been slow, hence processors operate below their installed capacity during most of the year.

Small processors dominate in terms of numbers, and they process a significant share of sunflower seed from smallholder farmers, but they also have low oil extraction efficiency. The owners of processing plants are mostly men. Overall, the sunflower value chain is characterised by low-women participation at higher levels of the value chain (marketing, processing). They are instead concentrated at lower-return nodes of the value chain (farming). Permanent employment at the mills is also dominated by men, except for some specialised activities such as winnowing. Women have also found some employment in reprocessing the sunflower slurry residue, owing to the low extraction capacity of processing technologies that is commonly used. For this reason, TASUPA would like the country to move away from some of the small processing machines by imposing minimum standards for imported machinery (personal communication with TASUPA chairman). Small processors choose to remain small to be in the non-VAT tax bracket, instead paying an alternative tax based on a flat rate and not tied to revenue. TASUPA would like to see that the small processors are VAT registered, because their potential for growth is limited by not paying VAT. It is not clear if TASUPA's stance is supported by all small processors.

Most of the small processors are located in remote villages that are connected to electricity, making it easier for farmers to access processing services, and livestock owners also retain their seedcake and use it for fattening their work animals. Cultural barriers such as limitations imposed on women travelling outside of their villages, and the fact that lucrative markets for their products are often far away, presents a barrier for women's participation in some of the more rewarding parts of the value chain. Women also lack access to credit more often than their male counterparts. They often rely on their networks and collective action such as village community banks and other self-help groups. There is a need for the government to assist such women groups to be formalised so that they can access credit from formal and financial institutions as a group.

As discussed earlier, the main competition limiting the expansion and improvement of the sunflower subsector comes from imported palm oil (refined and crude), which supplies more than half of the country's demand for edible oil. The declining global price of palm oil makes it cheaper locally, even with the new tariff, attracting many low-end consumers to switch to the less expensive substitute. It should be expected that the importers will try to use their long-standing interaction with policymakers to perpetuate the image of supply deficit in order to justify imports. The perceived failure of the recent import tariff structure to bring expected results in terms of stimulating immediate local productivity and production, thereby reducing farm gate prices for sunflower producers, may reflect the extent of such influence, or the ability of importers to circumvent the new regulation. It seems too early to conclude that the policy initiatives have failed, but it is necessary to address identified weaknesses such as the unintended effect of tariffs on imported edible oil on the local soap industry, making investors and labourers in the soap industry worse off, and widening the social difference gap for them.

Despite the temporary disruption in the supply of sunflower seed to processors, and processed oil and sunflower seedcake to consumers due to the COVID-19 
pandemic, the situation in Tanzania is almost back to normal as far as market operations are concerned. Local markets have opened since July 2020, and demand for sunflower seed and oil has increased. However, the demand for sunflower seed cake remains a challenge due to prevailing checks for health and quarantine requirements for drivers transporting cargo across borders, as well a slow recovery of maritime trade to importing countries such as India.

The sunflower sector strategy has been implemented since 2016. Smallholder farmers who dominate the market face low productivity and poor markets. The strategy aims at supporting farmers focusing on improving farm productivity, especially among smallholders, and improve the level of trust between farmers and processors, such that neither undermines the other through pricing and the quality of inputs (sunflower seed). This working paper has discussed many challenges and shortcomings facing the sunflower sub-sector. A candid assessment of their current status and the prevailing opportunities, will help to inform policymakers on the next blueprint for developing the sector in ten years and beyond. 
Balchin, N.; Kweka, J. and Mendez-Parra, M. (2018) 'Tariff Setting for the Development of the Edible Oil Sector in Tanzania', Unpublished report prepared to Balchini et al., Tanzania, http://dev.Balchini et al.or.tz/wp-content/ uploads/2018/04/I4ID-Tariff-setting-in-Tanzanias-edible-oil-sector_FINAL-Report_26-Feb-2018.pdf (accessed 16 March 2020)

Chisoro-Dube, S.; Paremoer, T. and Jahari, C. et al. (2018) Growth and Development of the Oilseeds-Edible-Oils Value Chain in Tanzania and South Africa, CCRED Working Paper 3, Johannesburg, South Africa

Dalberg, (2019) 'Progress Review of Industrialization in Tanzania's Sunflower Sector'.

FAOSTAT (fao.org/en/\#QC); FAO meta data for Tanzania (various years)

Hellen, D., and Hossain, N. (2018) Social difference and Women's Empowerment in the Context of the Commercialisation of African Agriculture, APRA Working Paper 8, Brighton: Future Agricultures Consortium

Kombe, C. et al. (2017) Potentiality of Sunflower Sub-sector in Tanzania, Bank of Tanzania, Working paper No. 10, https://www.bot.go.tz/Publications/Working\%20Papers/Potentiality\%20of\%20Sunflower\%20Sub-sector\%20 in\%20Tanzania.pdf (accessed 10 April 2020)

Otto, O.; Isinika, A. and Musahara, H. (2019) 'When Customary Land Tenure Meets Land Markets: Sustainability of Customary Land Tenure in Tanzania' in O. Otto, A. Isinika and H. Musahara (eds.), Land Tenure Dynamics in East Africa: Changing Practices and Rights to Land, Uppsala: Nordiska Afrikainstitutet

Isinika, A. et al. (2020) Does Rice Commercialisation Impact on Livelihoods? Experience from Mgeta in Kilombero District, Tanzania. APRA Working Paper 30, Brighton: Future Agricultures Consortium

Isinika, A. and Mwajombe, K. (2019) 'Sunflower Commercialization in Tanzania', unpublished research report

Isinika, A. and Mutabazi, M. (2010) 'Gender Dimension of Land Conflicts: Examples from Njombe and Maswa Districts in Tanzania' in K. Havnevick and A. Isinika (eds.), Tanzania in Transition: From Nyerere to Mkapa, Dar es Salaam: Mkuki na Nyota, pp. 137 -157, ISBN 978-9987-080086-1

Koda, B.O. (2000) "The Gender Dimension of Land Rights in Tanzania. A Case Study of Msindo Village, Same District." PhD thesis, University of Dar es Salaam

Magomba, C. and Boniface, G. (2020). 'The Current Status of Sunflower Processing Potential', unpublished report on sunflower processing for value addition and improved commercialisation in Singida Region, Tanzania

Mdoe, N.; Mlay, G. Isinika, A., Boniface G. and Magomba, C. (forthcoming) 'Livestock, Crops, Commercialisation and Livelihoods Among Rural Households in Singida Region, Tanzania' (forthcoming)

Markelova, H. and Mwangi, E. (2010) 'Collective Action for Smallholder Market Access: Evidence and Implications for Africa', Review of Policy Research, 27(5): 621-640

Mgeni, C.P., Müller, K. and Sieber, S. (2018) 'Sunflower Value Chain Enhancements for the Rural Economy in Tanzania: A Village Computable General Equilibrium-CGE Approach', Sustainability, 11(1): 75.

NBS and OCGS (2013) 2012 Population and Housing Census: Population Distribution by Administrative Areas, Dar es Salaam: National Bureau of Statistics

RLDC (2010) 'Sunflower Production Situation in the Central Corridor of Tanzania', report commissioned by Rural Livelihood Development Company, unpublished, Dodoma, p. 45 
Salisali, B.M. (2017)'Fiscal Policy Study on Edible Oil Sector in Tanzania', draft consultancy report for the Tanzania Private Sector Foundation, Dar es Salaam

Selemani, R. (2018) 'Local and Regional Variations in Conditions for Agriculture and Food Security in Tanzania: A Review', research report for AgriFoSe2030, Uppsala, https://www.researchgate.net/publication/328306767_ Local_and_regional_variations_in_conditions_for_agriculture_and_food_security_in_Tanzania_A_review (accessed on 30/04/2020)

URT (2016) 'Sunflower Sector Development Strategy: 2016-2020', Minister for Agriculture, Livestock and Fisheries, Minister for Industry, Trade and Investment. Dar es Salaam: United Republic of Tanzania, p.97

URT (2013) 'Scaling Up Renewable Energy Programme (SREP)', Investment Plan for Tanzania, Ministry of Energy and Minerals, Dar es Salaam: United Republic of Tanzania

Zilihona, I.J.E.; Mwatawala, H.W. and Swai, E.Y. (2013) 'Sunflower Production and its Contribution to Poverty Reduction in Singida District, Tanzania.' Presented at REPOA's $18^{\text {th }}$ Annual Research Workshop, Dar es Salaam, April 3-4, p.70 


\section{APPENDIXES}

Appendix 1: Selected medium and large-scale old and new edible oil

processors in Tanzania

\begin{tabular}{|c|c|c|}
\hline $\begin{array}{l}\text { Palm oil and sunflower } \\
\text { importer refineries }\end{array}$ & Sunflower crusher-refiners & Sunflower extractors \\
\hline \multirow[t]{2}{*}{$\begin{array}{l}\text { Muzar } \\
\text { Location: Dar-es-Salaam } \\
\text { Status: old } \\
\text { Method: crushing } \\
\text { Capacity: } 36,000 \text { million t/year }\end{array}$} & $\begin{array}{l}\text { Sunshine } \\
\text { Location: Singida } \\
\text { Status: old } \\
\text { Method: crushing, refining crude } \\
\text { Capacity: } 30,000 \text { million t/year }\end{array}$ & $\begin{array}{l}\text { Mount Meru } \\
\text { Location: Arusha } \\
\text { Status: old } \\
\text { Method: crushing, solvent } \\
\text { Extraction: refining crude } \\
\text { Capacity: } 110,000 \text { million t/year }\end{array}$ \\
\hline & $\begin{array}{l}\text { PYXUS } \\
\text { Status: New } \\
\text { Method: Crushing, refining crude } \\
\text { Capacity: 4,000; expanding to } \\
\qquad 120,000 \text { million t/year }\end{array}$ & $\begin{array}{l}\text { Jie Long } \\
\text { Location: Shinyanga } \\
\text { Status: old } \\
\text { Method: crushing, solvent } \\
\text { Extraction: refining crude } \\
\text { Capacity: } 45,000 \text { million t/year }\end{array}$ \\
\hline \multirow[t]{2}{*}{$\begin{array}{l}\text { Mohamed Enterprise Ltd. } \\
\text { Location: Dar-es-Salaam } \\
\text { Status: old } \\
\text { Method: crushing } \\
\text { Capacity: unknown }\end{array}$} & $\begin{array}{l}\text { Gilitu Enterprises } \\
\text { Location: Shinyanga } \\
\text { Status: new } \\
\text { Method: crushing, refining crude } \\
\text { Capacity: } 30,000 \text { million t/year }\end{array}$ & $\begin{array}{l}\text { Kahama Cotton Co. Ltd Lo- } \\
\text { cation: Kahama } \\
\text { Status: new } \\
\text { Method: crushing, solvent } \\
\text { Extraction: refining crude } \\
\text { Capacity: unknown }\end{array}$ \\
\hline & $\begin{array}{l}\text { Nyarusai Limited } \\
\text { Location: Kahama } \\
\text { Status: new } \\
\text { Method: crushing, refining crude }\end{array}$ & \\
\hline
\end{tabular}

Source: Adapted from Dalberg (2019) 


\section{Appendix 2: Wealth ranking criteria for qualitative study in Iramba and}

Mkalama districts, Singida Region

\begin{tabular}{|c|c|}
\hline Low wealth rank & Middle wealth rank \\
\hline - House of mud walls or raw brick & $\begin{array}{l}\text { - Walls of burnt brick or mud brick, if cement brick it is } \\
\text { smaller than high wealth rank }\end{array}$ \\
\hline $\begin{array}{l}\text { - Roof of grass (tembe), if corrugated iron (slope) } \\
\text { slopes one side only and mud smeared floor }\end{array}$ & $\begin{array}{l}\text { - Walls of burnt brick or mud brick, if cement brick it is } \\
\text { smaller than high wealth rank }\end{array}$ \\
\hline - Glass windows or planning to install them & - Roof of corrugated iron and cement floor \\
\hline - $0.4-2$ ha of land & -2-20ha (depending on the village) \\
\hline - 0-4 cattle or some goats often as caretaker for others & - 4-49 cattle and goats \\
\hline - May use only hand hoe & - May hire tractor \\
\hline - Gets 2-9 bags of sunflower & - Owns 1-3 oxen pair \\
\hline - $1-2$ meals per day & - 2-3 meals/day \\
\hline - Solar of 1-2 bulbs or use kerosene lamp & - Food lasts 12 months \\
\hline \multirow[t]{5}{*}{ - Poor quality clothes } & $\begin{array}{l}\text { - May have IGA e.g. kiosk, selling crops, food vending, } \\
\text { boda-boda }\end{array}$ \\
\hline & - May provide some seasonal employment \\
\hline & - Own bicycle or motorcycle \\
\hline & - Solar 2-3 bulbs \\
\hline & - Better quality clothes \\
\hline \multicolumn{2}{|l|}{ High wealth rank } \\
\hline $\begin{array}{l}\text { - Walls burnt bricks or cement blocks, corrugated iron } \\
\text { roof and glass windows }{ }^{4}\end{array}$ & - Some own tractor \\
\hline - Good furniture & - 3 meals/day \\
\hline - VIP toilet & - Food lasts 12 months \\
\hline - Own 20-300 cattle and goats & $\begin{array}{l}\text { - Medium sized solar } 3-4 \text { bulbs or enough for lighting } \\
\text { every room or connected to national electricity (REA } \\
\text { or TANESCO) }\end{array}$ \\
\hline - Own $>10->50$ acres (depending on the village) & $\begin{array}{l}\text { - Own IGA (e.g. buying and selling crops, buying and } \\
\text { selling cattle, shop) }\end{array}$ \\
\hline - Own 5 oxen pairs & - Owns motorcycle or car \\
\hline - $1-2$ ox carts & - Good clothes ${ }^{4}$ \\
\hline
\end{tabular}

Source: APRA Tanzania survey (2019) 


\section{ENDNOTES}

1 The Ministry of Agriculture has been named differently over time depending on its composition. Currently the ministry caters for agriculture food security and cooperatives

2 Personal communication with staff from Ministry of Agriculture (17/02/2021)

3 Boda-boda is a business where motorcycles are hired to transport

$4 \quad$ This may however not be true for pastoralists, who may own large herds of cattle but wear poor quality dress and live in very poor quality houses due to their nomadic lifestyle 
Isinika A.C. and Jeckoniah, J. (2021) The Political Economy of Sunflower in Tanzania: A Case of Singida Region, APRA Working Paper 49, Brighton: Future Agricultures Consortium

(c) APRA 2021

ISBN: 978-1-78118-772-2

https://doi.org/10.19088/APRA.2021.002

\section{(cc) BY-NC-ND}

This is an Open Access report distributed under the terms of the Attribution-Non Commercial-No Derivs 4.0 Unported (CC BY-NC-ND 4.0) Attribution - You must give appropriate credit, provide a link to the license, and indicate if changes were made. You may do so in any reasonable manner, but not in any way that suggests the licensor endorses you or your use. NonCommercial — You may not use the material for commercial purposes. NoDerivatives - If you remix, transform, or build upon the material, you may not distribute the modified material. You are free to: Share - copy and redistribute the material in any medium or format.

https://creativecommons.org/licenses/by-nc-nd/4.0/legalcode

If you use the work, we ask that you reference the APRA website (www.future-agricultures.org/apra/) and send a copy of the work or a link to its use online to the following address for our archive: APRA, Future Agricultures Consortium, University of Sussex,

Brighton BN1 9RE, UK (apra@ids.ac.uk)

All APRA Working Papers go through a review process before publication.

cc) commons

DO YOU HAVE COMMENTS ON THIS PAPER?

We would welcome your feedback on this working paper!

To provide brief comments, please follow this link to our short APRA Working Paper Feedback form: https://goo.gl/forms/1iVnXhhrIGesfR9

Agricultural Policy Research in Africa (APRA) is a programme of the Future Agricultures Consortium (FAC) which is

generating new evidence and policy-relevant insights on more inclusive pathways to agricultural commercialisation in sub-Saharan Africa. APRA is funded with UK aid from the UK Foreign, Commonwealth \&

Development Office (FCDO) and will run from 2016-2022.

The APRA Directorate is based at IDS, UK (www.ids.ac.uk), with regional hubs at the Centre for African Bio-Entrepreneurship (CABE), Kenya, the Institute for Poverty, Land and Agrarian Studies (PLAAS), South Africa, and the University of Ghana, Legon. It builds on more than a decade of research and policy engagement work by the Future Agricultures Consortium (www.future-agricultures.org) and involves more than 100 researchers and communications professionals in Africa, UK, Sweden and USA.

Funded by
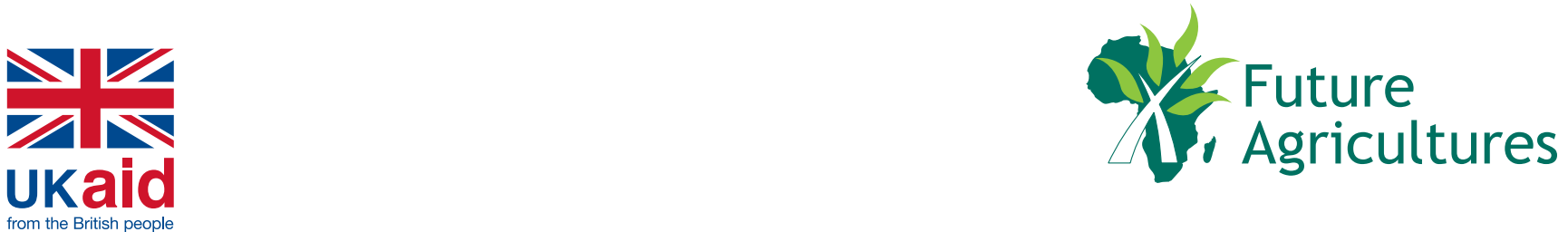